\title{
The implications of group norms for adaptation in collectively managed agricultural systems: evidence from Sri Lankan paddy farmers
}

\author{
Arielle Tozier de la Poterie $^{1}$, Emily K. Burchfield ${ }^{2}$ and Amanda R. Carrico ${ }^{3}$
}

\begin{abstract}
A growing literature seeks to explore the factors shaping adaptation to climate change. In collectively managed common pool resource systems, there is often a tension between behavior that benefits the individual and actions that benefit a larger group. Resource users in sustainable systems must therefore work together to ensure outcomes that are beneficial to the group as a whole. However, in the face of changing social, political, and environmental conditions, community norms may change, leading to the emerging of new behavioral patterns. Understanding when and why people decide to act in ways that benefit the group as a whole can help policy makers better target policies or change incentives to promote desired outcomes. This research seeks to build on research in common pool resource management and multilevel selection to understand how and why collective pressures shape individual adaptation behavior. Using qualitative data from in-depth interviews of farmers in Sri Lanka, this study confirms that collective management practices in Sri Lankan irrigation systems significantly influence farmer's potential adaption behaviors. Based on farmer's explanations of their own behavior, we hypothesize that farmer's belief in the ecological necessity of cooperation and explicit government support for collective action are important drivers of collective action. Given the influence of community rules and norms, we conclude that efforts at adaptation are more likely to be successful if they target farmer organizations and communities as a whole rather than individual farmers.
\end{abstract}

Key Words: agriculture; climate change adaptation; common pool resources; community-based irrigation; decision making; institutions

\section{INTRODUCTION}

In the face of climate change, academics and policy makers are concerned with how to promote adaptation in agricultural systems to protect food, water, and livelihood security. Adaptive behavior is shaped by policies and norms at various scales, ranging from the household level to national and international bodies (Cash et al. 2006). If we are to design effective policies and programs to support agricultural adaptation, it is necessary to understand the various forces that facilitate or constrain the decisions and actions of farmers around the world.

In this paper, we focus specifically on the factors shaping decision making in small, collectively managed irrigations systems in Sri Lanka. Community-managed resources such as forests, fisheries, and irrigation systems support the livelihoods of people around the world. It has been well established that the successful management of irrigation systems often requires high degrees of coordination (Ostrom 1993, Sarker and Itoh 2001, Trawick 2001). In order for water to be efficiently managed and delivered, such coordination must take place at levels appropriate for the size of the system in question, for example, at the level of the reservoir, the level of the distribution canal, and the field canal level in larger systems (Uphoff et al. 1990). In Sri Lanka alone, there are over 11,000 small-scale, farmer-managed irrigation schemes (Shah et al. 2013). Often communities have managed collective resources for generations; yet, as social, political, and economic conditions change, so do the incentives shaping individual and collective behavior. Changing contexts have the potential to erode or alter cultural norms and collaborative institutions in ways that can impact both resource management and adaptive capacity (Wilson et al. 2013, Waring et al. 2015). Warring et al. (2015) demonstrated in the context of Fijian fishing communities that the transition from fishing for local or subsistence use to selling to global markets contributed to overfishing by eroding cultural norms that promoted sustainable resource use. Other work has demonstrated that demographic changes, such as urbanization and population growth, can undermine the effectiveness of collective resource institutions (Cox and Ross 2011).

These examples raise questions of how cultural norms and institutions evolve in response to changing contexts. To devise effective policy, decision makers must understand the social, economic, and cultural factors that most influence individual decision making, how these forces interact, and the scales at which they operate (Cash et al. 2006, Brewer 2015, Waring et al. 2015, Waring and Tremblay 2016). However, little is known about precisely when, why, and how cooperation prevails over individualistic behavior (Waring et al. 2015). This analysis seeks to integrate insights from the common pool resource (CPR) and cultural multilevel selection (CMLS) literature, and responds to calls for case studies that can help elaborate a more robust theory of adaptation behavior.

Case studies are particularly useful in understanding the development and persistence of cooperative behavior because they provide an in-depth understanding of why people behave as they do (Brewer 2015, Waring and Tremblay 2016). By examining how people understand their own decisions, we can gain important insights into community dynamics (Brewer 2015) that might help policy makers design effective, context-relevant adaptation policies (Waring and Tremblay 2016). Drawing on this approach, we address the following research questions:

1. How do farmers themselves understand the pressures they face?

${ }^{1}$ Center for Science and Technology Policy Research, Department of Environmental Studies, University of Colorado Boulder, ${ }^{2}$ Department of Environment and Society, Utah State University, ${ }^{3}$ Department of Environmental Studies, University of Colorado at Boulder 
2. Which scale of decision making, individual or collective, is dominant in small-scale irrigation systems in Sri Lanka today? Do collective norms and practices prevail over individual decisions in modern times?

3. What are the implications of the answers to research questions one and two for adaptation policy?

We draw on the literature on common pool resource management and cultural evolution, both of which have significant implications for the design and implementation of climate change adaptation initiatives. Both recognize that the fitness of the group is dependent upon individuals foregoing individual benefits in favor of behavior that benefits the group as a whole (Olson 1965, Williams 1966, Hardin 1968, Ostrom 1990, Adger 2003). The CPR literature describe these tensions in terms of free-riders, individuals who benefits from a resource without sufficiently contributing to its management or maintenance. If the majority of resource users act in the best interest of the group, the impact of the free-riders may be minimal (Ostrom and Gardner 1993). However, many delinquent users eventually lead to resource or system degradation and the tragedy of the commons (Hardin 1968). Despite the potential for tragedy, Ostrom (1990, 1993) identified eight "design principles" that have proven critical for the successful management of long-enduring, common pool resources, including collectively managed irrigation systems.

Modern scholars of cultural evolution in general, and CMLS in particular, have developed a complementary line of research that seeks to explain and predict when individuals will collaborate and when they will act in their own self-interest (Traulsen and Nowak 2006, Waring et al. 2015, Waring and Tremblay 2016). Evolutionary models show that when multiple groups compete against one another for survival in the same environment, groups that cooperate are more likely to survive and multiply (Traulsen and Nowak 2006). Waring et al. (2015) hypothesize that when tensions exist between individual and group selection, "the social scale of an environmental dilemma determines the spread of a cooperative trait" (Waring et al. 2015:Fig. 2). CMLS theory builds upon the idea that evolutionary selection works at the individual and group levels, hypothesizing that over-time groups that develop effective cultural mechanisms for ensuring cooperation will be more likely to survive and multiply than groups of more self-interested individuals (Waring et al. 2015, Richerson et al. 2016). The CMLS framework can be used to generate hypotheses about sustainable practices, to explore how sustainable practices evolve, and to understand how and why they persist (Waring et al. 2015).

First, we examine how resource users in a modern common-pool resource system have responded to changing social, political, and economic pressures and identify how individual and collective considerations influence farmer decisions. We conclude that, unlike what Waring et al. (2015) found in Fiji, marketization, mechanization and other forces associated with colonization and modernization have changed how farmers cultivate, e.g., how much land is farmed and the techniques used, but that collective norms historically associated with paddy cultivation practices remain strong.

Second, the depth of our qualitative data allows us to hypothesize about why collective norms have persisted. In doing so, we respond to calls to develop hypotheses about the factors influencing whether individual or group selection will dominate decision making in a given context (Waring and Tremblay 2016). Based on our informants' accounts of the factors influencing their decision making, we hypothesize that explicit recognition of and belief in the ecological (and hence economic) consequences of defection and government support for collective action have contributed to continued collaboration in the face of social, political, and economic change.

We demonstrate how insights from CMLS analyses can be useful for adaptation policy makers. Despite increasing acknowledgment of the role individual or group incentives may play in shaping adaptive behavior (Waring and Tremblay 2016), our research team's experience in Sri Lanka suggests that on-the-ground adaptation in Sri Lanka is often targeted at individual farmers (Villholth and Rajasooriyar 2010). For example, government institutions promote a variety of practices, e.g., crop diversification or hybrid seed varieties, to encourage resilience to water scarcity and other climate-related shocks. Yet, these efforts (in the form is pamphlets and farmer training programs) often target individual farmers rather than encourage collective shifts toward such practices. We therefore elaborate on the policy implications of group selection pressures and community dynamics that we observed, concluding that adaptations targeted at the community as a whole are more likely to be effective.

\section{BACKGROUND}

\section{Climate change adaptation and adaptation strategies}

A growing body of literature explores the importance of community and individual strategies to adapt to climate change. This includes responses that are adopted autonomously by households as well as those promoted through governmental or nongovernmental institutions. Adaptive strategies in agricultural systems may include crop and livelihood diversification (Kurukulasuriya and Mendelsohn 2008, Wassmann et al. 2009, Dasinaa and Sugirtharan 2017), the introduction of agricultural insurance schemes (Wassmann et al. 2009, Varela-Ortega et al. 2016, Dasinaa and Sugirtharan 2017), or the use or promotion of indigenous and technical knowledge (Wassmann et al. 2009). In water-scarce regions such as the Sri Lankan dry zone, adaptations include increasing reservoir capacity and water-use efficiency through water harvesting and practices that conserve soil moisture in dry areas or prevent soil erosion and water logging in wet areas (Wassmann et al. 2009, Babel et al. 2011, VarelaOrtega et al. 2016). Paddy-specific adaptations include choosing paddy varieties that are better suited to the new climate (Wassmann et al. 2009, Babel et al. 2011, Varela-Ortega et al. 2016, Dasinaa and Sugirtharan 2017), changing planting and harvesting schedules (Babel et al. 2011, Banerjee et al. 2016, Shrestha et al. 2016, Dasinaa and Sugirtharan 2017), transplanting seedlings (Banerjee et al. 2016), alternate wetting and drying of paddy to reduce irrigation water requirements (Rejesus et al. 2011, Dasinaa and Sugirtharan 2017), and improving pest and disease management through integrated pest management and the selection of disease and pest resistant varieties (Wassmann et al. 2009).

The Sri Lankan Government acknowledges that agricultural adaptation has the potential to significantly reduce the impact of 
Table 1. Applicability of Ostrom's $(1990,1993)$ design principles to historic patterns in Sri Lankan minor irrigation systems.

\begin{tabular}{|c|c|}
\hline$\underline{\text { Design principle }}$ & Historical characteristics of Sri Lankan minor irrigation systems \\
\hline 1. Clearly defined boundaries & These systems had clearly defined boundaries (Guneratne 1985, Abeyratne and Perera 1986) \\
\hline $\begin{array}{l}\text { 2. Proportional equivalence between costs and } \\
\text { benefits }\end{array}$ & $\begin{array}{l}\text { Land holders were obligated to contribute labor for collective works in proportion to the amount of } \\
\text { land they held (Leach 1961, Dayton-Johnson 2003). }\end{array}$ \\
\hline 3. Collective-choice agreements & $\begin{array}{l}\text { At the beginning of every cultivation season, farmers participated in creating the rules governing } \\
\text { planting, water releases, system maintenance, monitoring, and sanctions (Somasiri 2008, Jinapala et } \\
\text { al. 2010). }\end{array}$ \\
\hline 4. Monitoring & Communities had mechanisms for monitoring adherence to the rules (Leach 1961). \\
\hline 5. Graduated sanctions & Communities settled disputes through village tribunals and regional courts (Leach 1961). \\
\hline 6. Conflict resolution mechanisms & Community members resolved disputes among themselves (Mohottala Gedara 2011). \\
\hline 7. Minimal recognition of rights to organize & According to Leach (1959) ruling elites did not interfere with management of the village tanks. \\
\hline 8. Nested enterprises & $\begin{array}{l}\text { This was irrelevant in a more decentralized time, when state authorities did not interfere in village } \\
\text { affairs (Leach 1959). }\end{array}$ \\
\hline
\end{tabular}

Source: Adapted from Ostrom (1993).

climate change on farmer livelihoods (Reidsma et al. 2010, Shrestha et al. 2016). Mitigating the impacts of climate change on agriculture is one of six strategic priorities outlined in the National Climate Change Adaptation Strategy (Government of Sri Lanka, 2010a). Recent government reports advocate research for and the promotion of traditional, indigenous rice varieties, noting that widely used "improved," imported varieties that promise higher yields are more susceptible to pests and diseases, require more agricultural inputs, and are not well adapted to local climate conditions (Government of Sri Lanka 2010b). Sri Lankan policy makers advocate crop diversification and the cultivation of less water-intensive, nonpaddy crops such as chilies, onions, and soy to reduce water demand. In addition, the government acknowledges the need for environmental protection and conservation through the prevention of land degradation, soil conservation, and a reduction of chemical fertilizer and pesticide use. Finally, the government promotes the conservation of indigenous knowledge of Sri Lanka's unique agro-ecology and climate because it believes such knowledge will be useful in adapting to climate change (Government of Sri Lanka 2010b).

\section{Study site}

In Sri Lanka, rice (paddy) cultivation has been the bedrock of economic, social, and cultural practice since before 67 CE (Peebles 2006). Paddy cultivation in Sri Lanka takes place during one or both of two distinct monsoons seasons, the maha and yala. The maha rains last from October to December and bring nearly $75 \%$ of annual rainfall to the island (Senaratne and Scarborough 2011). The spatial distribution of rainfall divides the island into three agro-ecological zones: the dry zone, intermediate zone, and wet zone (Lyon et al. 2009). Today, nearly three quarters of Sri Lanka's paddy production is concentrated in the intermediate and dry zones (De Silva et al. 2007) where irrigation is essential to farmers' ability to cultivate in both the yala and maha seasons. The dry zone is therefore covered with both major and minor systems. In minor systems, precipitation is captured in rain-fed tanks and distributed through a system of dug canals maintained by the water users (Panabokke et al. 2002), and in major systems water is diverted from the nation's largest river through a series of state-managed reservoirs and canals. Although the government has invested heavily in the development of major irrigation systems since the 1960 s, there are still over 11,000 minor systems covering the island (Shah et al. 2013). Successful, multiscalar agricultural adaptation will be essential across systems to maintain food and water security and support local agricultural livelihoods.

Sri Lankan minor tank systems as common pool resource systems A great deal has been written about irrigation systems as common pool resources (CPRs) and about the conditions under which collectively managed CPR systems are most likely to ensure sustainable resource management (Freeman 1990, Ostrom 1993, Sarker and Itoh 2001, Trawick 2001, Bardhan and DaytonJohnson 2002, Bastakoti and Shivakoti 2009, Madani and Dinar 2012). As summarized in Table 1, scholars historically described small-scale irrigation systems in Sri Lanka in ways that are consonant with Ostrom's design principles. Canals leaving the tank irrigate long thin plots of land that run parallel to the tank bund, the earthen structure that retains the water (see Fig. 1). Each farming family received a parcel of land in the head-, middle-, and tail-end of the tank's command area, promoting equity in access to the shared water supply (Leach 1961).

Fig. 1. Layout of minor village irrigation system.

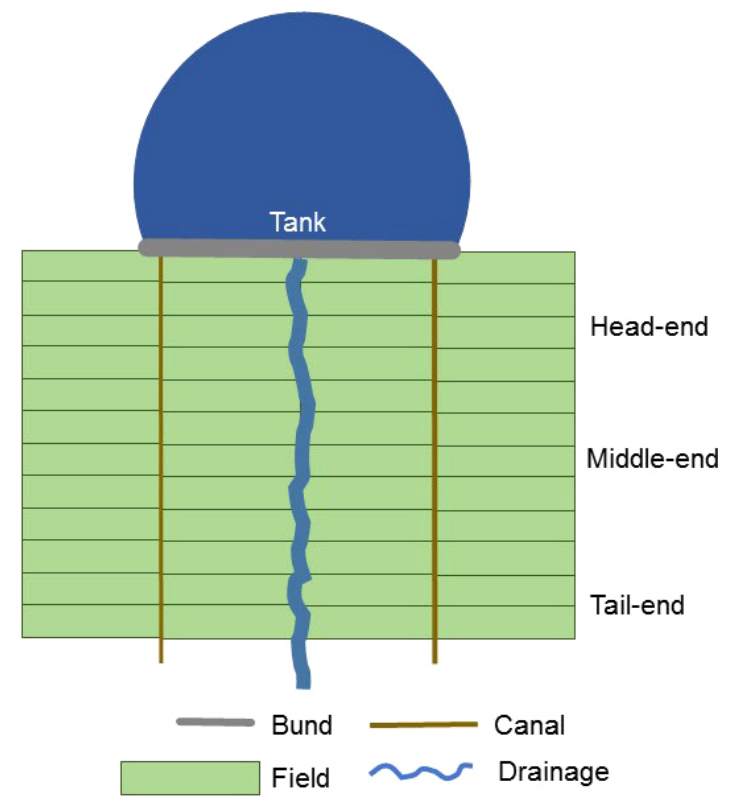


Allocating the easily irrigated head-end land to all families in the community ensured that everyone would be able to cultivate in times of water scarcity. During times of extreme water scarcity, farmers engage in a practice called bethma (Leach 1961, Thiruchelvam 2010), in which the area of land cultivated was reduced and reallocated among farmers based on their land holdings to ensure that everyone was able to cultivate (Somasiri 2008).

\section{Changing systems}

Sri Lanka has undergone significant social, political, and economic changes, which have the potential to erode or support community institutions and lead to more individualistic behavior. For example, a number of colonial and postindependence policies have gradually given the government greater influence over management of irrigation of minor systems, land tenure and cultivation, and the crops cultivated. Since WWI, the government has enacted several policies to ensure that Sri Lanka is selfsufficient in paddy production (Anderson et al. 1991, Ariyabandu 2008) including laws that forbade farmers from growing crops other than rice (Yamane 2009). In the late 1950s, the Department of Agrarian Development began to oversee maintenance of small tanks and management activities, such as the holding of preseasonal farmer meetings, which dictated the timing of paddy cultivation, soil conservation practices meetings (preseasonal farmer meetings), and paddy cultivation timing and soil conservation practices, discussed at greater length below (Dunham 1982).

In addition to policy changes, famers have gradually adopted modern agricultural technologies such as non-native seeds, mechanized equipment, chemical fertilizers, and pesticides. The Green Revolution brought the development of short-duration rice varieties, which allowed farmers to shorten the maha cultivation season by a month (Anderson et al. 1991). It also brought fertilizer, introducing the need for credit. Beginning with the Paddy Lands Act of 1958, the government encouraged the use of chemical fertilizers by mandating that a proportion of the price paid to farmers for their rice be paid in fertilizers and other farm inputs (Anderson et al. 1991, Weerahewa et al. 2010). Widespread access to fertilizer likely obviated, at least seemingly, the use of cow manure, land fallowing, or other traditional practices aimed at replenishing the soil. In 1958, a quarter of the paddy land was given synthetic fertilizer. By $1968,100 \%$ of paddy land was chemically fertilized (Anderson et al. 1991).

\section{METHODS}

This analysis emerged from a larger NSF-funded interdisciplinary research collaboration that examines various aspects of climate change adaptation, agricultural practices, and water scarcity in Sri Lanka's dry zone. Although the results presented here draw primarily on interview data from 39 individuals in 30 households in a single minor-tank village in the Anuradhapura region, the analysis and results were corroborated by interviews with officials at the national, regional, and local levels, as well as data from interviews with over 150 other major and minor system farmers conducted between 2013 and 2017. The village was selected as a representative case (Seawright and Gerring 2008, Yin 2013) in consultation with local research partners. Like many minor tank systems under the jurisdiction of the Department of Agrarian Development in Sri Lanka, it is a long-standing, majority
Sinhalese minor tank system community that has operated as a community-managed irrigation system for decades, if not centuries.

We analyzed the primary factors individual farmers described as influencing their individual and household decision making using data from in-depth interviews and participant observation. Data were collected between August and November of 2015, a period after the dry season (yala) harvest when communities are planning for the upcoming maha wet season. A team of four researchers (the first author and three Sri Lankan research assistants), conducted semistructured interviews in one major and one minor irrigation system in Anuradhapura District. The interview questions and protocol were derived from the livelihoods as intimate governance (LIG) approach to livelihood analysis (Carr 2014), a methodology designed to unpack the factors that shape individual's livelihood decisions.

In 2015 , the team interviewed the two local government officials responsible for system management, the system's extension officer, and farmers from 30 of the 71 farming households in the minor village. We also conducted a focus group of major and minor system farmers together to explicitly capture perceived differences between small and large irrigation systems.

For several months in 2015, the team lived in an adjacent farming community, traveling to and from the minor village to interview, observe, and interact with farmers. Participant observation consisted of accompanying farmers to their fields, attending the seasonal meeting, and observing seasonal tank and canal maintenance. The team conducted the interviews in Sinhala and research assistants translated the questions and answers into English. Because farmers were reluctant to have their interviews recorded, team members took notes throughout the interview and consulted in the evenings to create transcripts of the translations. Any quotations are based on direct translations by the interpreters, and farmers are identified by their confidential interview numbers.

Because the LIG method is designed to elicit an understanding of how different groups within a community make decisions, each farmer was asked a series of similar questions about their family history, agricultural practices, and any other livelihoods they practice or had practiced in the past. We attempted to understand what farmers "typically" do, asking about specific years in which water was known to be plentiful or scarce to elicit how water scarcity might influence decision making. Each interview was conducted with the primary agricultural decision maker in the household, though often other family members were present and contributed to the discussion ( 22 of the interviews were primarily with men, in 4 interviews the husband and wife participated equally, 4 interviews were with female famers, and in 2 interviews multiple generations of the same family contributed). At each stage, the team attempted to elicit why farmers made the decisions they did, especially when an individual expressed a unique preference or choice. By asking individuals for the rationale behind their choices, patterns of opportunity and constraint emerged, revealing the dominant contextual forces that influence farmer decision making. Both during and after data collection, the team coded the qualitative data for demographic information as well as differences and similarities in livelihood practices and themes relevant to livelihood decision making. 
Table 2. Ostrom's (1990, 1993) design principles in today's minor systems.

\begin{tabular}{|c|c|}
\hline Design principle & Evidence of persistent collective action \\
\hline 1. Clearly defined boundaries & $\begin{array}{l}\text { Those allowed to plant in the system are outlined in farmer organization (FO) documents. The list of } \\
\text { farmers is based upon a village deed outlining ancestral ownership of the land, as formalized by the British } \\
\text { during colonial times (INT 1, 2, 3, Local government official). }\end{array}$ \\
\hline $\begin{array}{l}\text { 2. Proportional equivalence between costs } \\
\text { and benefits }\end{array}$ & $\begin{array}{l}\text { "Labor [for tank preparation and bund maintenance] is divided proportionately to the land owned" (Local } \\
\text { government official). }\end{array}$ \\
\hline 3. Collective-choice agreements & $\begin{array}{l}\text { These exist, but are heavily influenced by government officials. When asked how they decided what seeds to } \\
\text { plant and when, most of the farmers recounted some version of "the kupanisa [government representative } \\
\text { from the Department of Agrarian Development] organizes the precultivation meeting, in which all the } \\
\text { decisions are made, and then farmers follow them" (INT 11). }\end{array}$ \\
\hline 4. Monitoring & $\begin{array}{l}\text { Community members monitor each other with assistance from the kupanisa as necessary (Local } \\
\text { government official). }\end{array}$ \\
\hline 5. Graduated sanctions & $\begin{array}{l}\text { Sanctions are outlined in the seasonal contract and are imposed either by farmer organization officials or } \\
\text { by the government official charged with enforcing the rules (Local government official). }\end{array}$ \\
\hline 6. Conflict resolution mechanisms & $\begin{array}{l}\text { In case of conflict or misbehavior, tract representatives first attempt to resolve disputes, escalating to the } \\
\text { kupanisa as necessary (Local government official). Elected FO presidents, secretaries, and tract } \\
\text { representatives are responsible for reminding people to pay their FO dues and perform their portion of } \\
\text { bund cleaning and canal and tank maintenance, as well as overseeing water allocation and attempting to } \\
\text { resolve any conflicts over water management (INT } 1,2,3 \text { ). The kupanisa has the final authority to punish } \\
\text { people through fines or withholding water when they do not comply with the rules (Local government } \\
\text { official). }\end{array}$ \\
\hline $\begin{array}{l}\text { 7. Minimal recognition of rights to } \\
\text { organize }\end{array}$ & $\begin{array}{l}\text { Farmer organizations are recognized by the government, which works closely with those organizations to } \\
\text { set seasonal rules (Local government official; INT } 1,2,3 \text { ). }\end{array}$ \\
\hline 8. Nested enterprises & $\begin{array}{l}\text { If unable to resolve problems themselves, farmers can also escalate complaints to local government } \\
\text { officials (INT } 1,20,35,36 \text {; Local government official). }\end{array}$ \\
\hline
\end{tabular}

Because of the cultural necessity of going through official channels, introductions to households were done in collaboration with officials from the farmer organization, an elected community body charged with overseeing preliminary enforcement of seasonal cultivation rules, and were based upon farmer availability during the time of our interviews. Close collaboration with local officials made it difficult to guarantee unbiased sampling; nevertheless, the team emphasized the need to speak to farmers representing the full-range of livelihood circumstances. We found that respondents, regardless of their age, gender, or apparent social class provided similar explanations of the nature of collective constraints to individual behavior. Because of the focus on collective constraints rather than intra-community differences in decision making, the inability to ensure a representative sample is unlikely to affect the results presented here. Finally, in 2017, the research team conducted an additional 7 interviews with 15 national-level officials involved in decisions related to farmer organization management, agricultural policy, and water management to ascertain how the degree to which the patterns observed below were representative of other minor systems.

\section{RESULTS}

Which level of selection dominates?

In this section we present our evidence regarding the level, individual or community, at which selection is strongest. Despite the many social, economic, and political changes that have taken place in Sri Lanka, there was overwhelming evidence that collective selection pressures remain intact. Ostrom's seventh design principle suggests that government interference with community organization and management of a resource may undermine collective management. We found that government interference has not eroded norms pertaining to crop selection and the timing of agricultural activities. Government interference in tank maintenance, however, appears to have had a negative influence on community member's willingness to maintain tank infrastructure. Table 2 summarizes the extent to which Ostrom's design principles and principles of collective action remain dominant today.

The farmers we interviewed described farming governance systems that retain many of the qualities of traditional minor irrigation systems, but with significant influence of government authorities over decision-making processes. According to government informants across the country, the management of minor systems is overseen by a combination of government officers and elected community officials who head the community farmer organization (FO). In minor systems, there is one FO per reservoir. All farmers in the community are generally members because government fertilizer subsidies and other services are distributed through FOs, effectively mandating membership. Before each season, members of the FO meet for precultivation and seasonal meetings in which they work with local officials to draft a management plan for the upcoming season. The rules and decisions outlined at the seasonal meetings include everything from the timing of water releases to farmer obligations to contribute to tank and bund maintenance, building fences to keep cattle out of the paddy fields, and organization to protect the fields from elephants. Once ratified by all the farmers and the kupanisa, a government representative from the Department of Agrarian Development (DAD) who is responsible for overseeing tank operations, the decisions taken at these meetings are legally binding. Violators may be fined, have water withheld, or may be otherwise punished as per the community rules.

According to official and farmer accounts, government experts use the seasonal meetings as a space to recommend and harmonize the use of specific seed varieties and management practices. The 
meetings are an opportunity for government experts to make crop and calendar recommendations for the upcoming season based upon water availability, pest control, and other factors. Farmers may make adjustments based upon their field characteristics and when exactly they are able to start cultivating, but for the most part they heed the recommendations of local authorities.

Our interviews indicated that farmers in minor systems only break with seasonal meeting guidelines in times of duress. According to farmers, illness or other personal and financial hardships impeding their ability to prepare land or obtain seeds, fertilizer, and other inputs were the only reasons they would not begin cultivation with their neighbors. Farmers call such delays "late cultivation" and although it may not be "a big issue in the maha season, as there is enough [rain] water, if this happens in yala, their harvest reduces. Therefore, they always try to go with the decisions in the seasonal meeting, especially in yala" (INT 27).

\section{Tank maintenance: a breakdown in collective action}

Water scarcity and the condition of infrastructure were the most commonly cited problems among farmers. According to both farmers and officials, poor infrastructural conditions are largely the result of disputed responsibilities for tank infrastructure. Farmers and officials each believe the other should do more to contribute toward infrastructure maintenance, a situation that negatively affects any attempts to reduce water losses due to declining infrastructure. Farmers pay into a FO fund each month and want that money to be used to address problems the community deems important. As noted by a local official, "one of the reasons that farmers are always asking [the government] to make renovations is because they know there are [FO] funds and they believe it is their money to spend." Farmers, however, have little control over when and how the FO funds are spent. The fund is managed by the DAD, and approvals for spending and repairs must go through the Divisional Officer at the DAD. The DAD's stance is that farmers should not use FO funds for work they can do themselves, even if the community would prefer to first pay someone else to do the work. Because the FO lacks the authority to compel farmers to engage in unpaid work on road or infrastructural repairs and the government refuses to authorize the distribution of funds for system repairs, the infrastructure deteriorates. As elaborated in the discussion, these disputes have significant implications for the potential to manage water losses and efficiency as a means of adaptation.

\section{Why does collective action persist?}

In addition to indicating that group-level selection pressures continue to dominate in minor tank systems in Sri Lanka, our interview data also provides insight into why such pressures continue to dominate. When asked why they adhere to seasonal rules, farmers cited interrelated social and ecological constraints to individual actions. None mentioned the threat of external sanctions. Farmers are well aware of the ecological constraints of irrigated paddy farming and of the individual and group repercussions of not synchronizing agricultural activities. Each stage of irrigated paddy cultivation, from land and bund preparation to harvest, depends on the proper timing of water release, access to fertilizer, chemicals, seeds, labor, and other inputs.

The need for collective water management is a basic fact of life in reservoir-irrigated agricultural systems; it is essential to successful yields. In the wet maha season, rules governing water release provide some flexibility so that the maximum amount of water can be retained in the tank for the dry yala season. Farmers consult with each other and agree on the releases based on weather and crop conditions, and it is therefore important that famers are in the same stage of cultivation. In the yala season, water release dates are precisely outlined and followed. Rather than measuring water use by the unit each farmer consumes, each farmer is allowed to draw water from the canal for a fixed period of time. In either season, conflicting water needs are managed according to the dates and rules outlined in the community contract. Therefore, if the community agrees to a rice variety that matures in 3.5 months, with a planting date of early December, water will be released based upon the needs for that variety, and those who start at different times or have chosen different varieties will have access to water at potentially suboptimal times.

Planting at the same time as other farmers also reduces susceptibility to pests. In the minor systems, "especially in paddy cultivation, farmers discuss with the neighbors and decide when to apply fertilizer and chemicals and which chemicals to apply because all the fields are in the same area as tracts, so it is easier for them to manage the fields in the same manner, otherwise pest and disease attacks are high" (INT 31). Given the layout of the tracts, a single farmer cannot protect his fields alone. Therefore, synchronization of crops and activities helps farmers distribute the risk of bird, elephant, and insect damage. Ecological pressures are perceived to be so strong that officials with the authority to punish farmers for not complying with group practices usually do not enforce the rules "because nature punishes them" instead (official).

Furthermore, these ecological realities have largely been reinforced by national policy. In contrast to Waring and Tremblay's (2016) description of events in Fiji, government officials recognize importance of collective principles to ensuring system productivity. Therefore, with the exception of allowing community members to control their own FO funds, government officials exert their influence in ways that reinforce collective management, such as supporting seasonal meetings and contracts and enforcing the rules established therein.

\section{DISCUSSION}

The continued dominance of collective action dynamics described above has significant implications for the ability of individual farmers to adapt to climate change independently of their neighbors. Our findings suggest that in the context of minor irrigation systems in Sri Lanka, efforts to conserve water, diversify crops, use alternative or traditional pest management techniques, change seed varieties, or change planting schedules are likely to be more effective at the community level because group selection pressures continue to dominate in these systems. Seasonal meetings and the drafting of community rules could be an opportunity for government officials and community members to work together to craft holistic adaptation action plans (and coinciding incentives) with the potential for addressing many adaptation goals, including water conservation and efficiency and diversifying agricultural crops (Government of Sri Lanka 2010b), in ways that benefit farmers and contribute to system sustainability. We elaborate the implications of collective management for each adaptation measure below. For the sake of 
Table 3. Summary of the relationship between adaptations and community coordination.

\begin{tabular}{|c|c|}
\hline Adaptation & Relationship to community coordination \\
\hline 1. Water conservation & $\begin{array}{l}\text { Effective water management requires actors to work together at the sluice, canal, and field-levels and } \\
\text { would be nearly impossible without coordination. Adaptations designed to manage water more efficiently } \\
\text { therefore need to be organized at the community level. }\end{array}$ \\
\hline 2. Crop diversification & $\begin{array}{l}\text { Because other field crops and paddy require different water regimes, and because water releases must be } \\
\text { coordinated at the community level, successful crop diversification in minor systems is likely to require } \\
\text { community-level coordination. }\end{array}$ \\
\hline 3. Pest management & $\begin{array}{l}\text { Farmers have a strong belief in the need to coordinate pest management; this belief is consistent with } \\
\text { integrated pest management strategies that target community-level coordination. Future research would be } \\
\text { needed to determine whether traditional pest management strategies require community-level coordination } \\
\text { to be successful. }\end{array}$ \\
\hline 4. Crop duration & $\begin{array}{l}\text { Community-level coordination of short- or long-term varieties ensures that farmers will receive water at } \\
\text { critical stages of plant development. Farmers can still choose specific varieties of short-duration seeds on } \\
\text { an individual basis, some of which might be more adaptive than others. }\end{array}$ \\
\hline 5. Changing planting times & $\begin{array}{l}\text { Farmers prefer to plant at the same time to ensure the availability of water at critical times in plant } \\
\text { development; farmers can and do make exceptions to this in case of illness or lack of resources (for } \\
\text { instance planting short-duration seeds if starting late and others are planting long-duration). }\end{array}$ \\
\hline $\begin{array}{l}\text { 6. Water conservation through } \\
\text { infrastructure maintenance }\end{array}$ & $\begin{array}{l}\text { Theoretically, infrastructure maintenance could be managed entirely by the community, entirely by the } \\
\text { government, or through some combination of the two. Whatever the choice, roles and responsibilities need } \\
\text { to be clearly defined, especially with regard to community funds, and agreed upon by both the community } \\
\text { and the government to ensure proper system maintenance and concomitant water conservation. }\end{array}$ \\
\hline
\end{tabular}

brevity, we focus only on those adaptations likely to be affected by the trends, rules, and norms outlined above. The relationship between each adaptation and community-level coordination is summarized in Table 3.

\section{Water conservation}

Improved water management, including alternate wetting and drying of paddy, is commonly cited as an important adaptation to climate change (Bouman et al. 2001, Belder et al. 2004, Belder et al. 2005, Rejesus et al. 2011). The nature of irrigation practices in minor irrigation systems means that any adjustments to watering patterns would likely need to take place at the community rather than the individual level. The amount of water released from the tank (and hence not saved for future cultivation) is determined by how long the sluice gate is left open. If one farmer chooses to use less water, the water will still be released downstream for other farmers to use instead of being saved for a future season. Only if all the farmers agree to draw water for a shorter period is water likely to be kept in the tank for future use. Likewise, because farmers need to draw water based upon coordinated water releases, it would be difficult for a single farmer to adopt alternate wetting and drying of paddy without coordinating with the entire community to ensure availability of water at appropriate times. Because effective water management would be nearly impossible without coordination, we conclude that any adaptations designed to manage water more efficiently would need to be organized at the community level. Water management also influences the need for coordination in several of the adaptations, described below.

\section{Crop diversification}

Likewise, collective water management constraints make it difficult for farmers to individually engage in crop diversification, a potentially important adaptive strategy during periods of water scarcity. Minor tank farmers are only able to grow other field crops (OFCs) in the maha season on nonirrigated land that is not subject to the same collective norms or pressures as irrigated paddy. As one farmer put it, "it is not possible to cultivate OFC on the tank land. All of the farmers cultivate together, so if only he is growing OFC it will cause problems for the management" (INT 14). Efforts at crop diversification on minor system paddy lands would therefore first need to address collective water and pest management constraints or encourage all farmers within the system to switch to OFCs.

\section{Pest management}

The potential for farmers to use traditional pest management techniques or to rely on integrated pest management are heavily influenced by the perceived need to coordinate with other farmers. Farmers who wish to use traditional or nonchemical, integrated pest control methods risk being the only farmer in the area who has not used harsh chemicals. Farmers fear being the only ones to use different techniques because they believe it makes them more susceptible to pests. Confirming farmers' fears that using different pest management practices puts them at greater risk of pest attack was beyond the scope of this study; nevertheless, the prevalence of this belief indicates that any efforts to change farmers' pest management practices must either address farmer concerns regarding outlying practices or be done through the FO and detailed in the seasonal rules.

Likewise, efforts to move toward integrated pest management (IPM) would also need to be organized at the community-level. The term IPM is often used in different ways (Kogan 1998, Peshin et al. 2009). It is therefore not a single method or strategy, but rather an approach to devising such strategies at various scales. We use it here to refer to decision support systems that help to select a combination of chemical and nonchemical pest control strategies based on economic, social, and environmental costs and benefits (Kogan 1998, Dhawan and Peshin 2009). Although ideally IPM would require farmers to integrate their pest management actions for a variety of pests and crops, in many instances "integration" refers only to integrating multiple methods to control a single pest or group of pests, with minimal 
community-level coordination (Kogan 1998, Peshin et al. 2009). Efforts at community-level action would be consistent with the community level coordination demanded by higher levels of IPM integration (Kogan 1998).

\section{Crop duration}

The use of short-duration crop varieties, which are bred to reduce the growing season duration and hence water requirements, is commonly suggested as an adaptation to conserve water. Although the farmers we spoke to were not always convinced that the short-duration seeds commonly recommended by the government were optimal in terms of water usage, pest resistance, and flavor, our informants indicated that the government already significantly influences the duration of seeds selected through its role in drafting seasonal contracts. Unless farmers have particularly low-lying or wet fields, they prefer to heed government recommendations to select short-duration seeds because adhering to recommended planting and maturation schedules ensures access to water during critical stages of plant development. However, none of our informants expressed ecological or social reasons for coordination of the precise varieties planted if development and maturation times are similar. To the extent that short-duration seed varieties succeed in conserving water, widespread use of short-duration seeds may be interpreted as an example of government-facilitated collective adaptation already in place in minor systems. However, because farmers still have leeway in choosing the precise variety of seeds to plant, they may still be able to individually adopt specific climate-adaptive varieties.

\section{Changing planting times}

At the collective level, the governance of Sri Lankan irrigation systems already facilitates changing of planting and harvesting dates in response to variations in climate and resulting water levels in the tank. System rules are formulated in advance of the season, but planting and harvesting dates are determined based upon the water available in the tank and the arrival of the seasonal rains. At the individual level, famers have little incentive to deviate from group rules by planting earlier, harvesting later, or using different seeds, each of which may result in "natural" penalties. In this case, institutions in Sri Lanka may already be positively influencing individual adaptation behavior.

\section{Water conservation through infrastructure maintenance}

Improving the condition of the infrastructure is likely to be an important factor in improving the efficient use of water, and hence to adapting to increasing water scarcity as predicted under climate change. Leaking sluices, crumbling canals, and other damaged infrastructure all contribute to water losses within the system. Unclear responsibilities for maintenance of the tanks has contributed to the decline in infrastructure conditions, presenting a significant barrier to efficient water management and hence to adaptation.

Such outcomes are predicted by Ostrom's design principles, which suggest that local autonomy to manage a resource is important to long-term sustainability. Although the government is also heavily involved in setting and enforcing cultivation rules, those rules are accepted by the community because of their obvious contribution to positive outcomes. In the case of FO dues and infrastructure maintenance, however, the government is not accountable to the resource users. By refusing to allow the farmers to use FO money as they see fit, the government creates resistance to collective maintenance practices and undermines collective action. FO dues are more like taxes paid to the government than a community managed fund intended to help the community meet its own needs and maintain infrastructure. Because both the government and the famers expect the other actor to eventually take responsibility for failing infrastructure, the system continues to erode with significant consequences for farmer livelihoods, agricultural productivity, and the possibility of more efficient use of water, as will be required by climate change. Confusion and conflict over responsibilities for FO funds and system maintenance will need to be addressed if minor tanks are to adapt to climate through more efficient use of water.

\section{Future research}

We hypothesize that two forces have helped Sri Lankan minor tank farmers sustain collective action in the face of rapid change. First, explicit articulation of and belief in ecological interdependence has led to the evolution rather than the breakdown of collective practices. Second, rather than seeking to entirely undermine or abolish local control, the government has been able to coordinate with and influence community processes for collective action. These conclusions, which are based on indepth, qualitative work, form a solid foundation for larger-scale studies or surveys testing the relationship of individual adaptations to collective action and the degree to which the existence of interdependence, belief in ecological interdependence, and government support for collective action are individually correlated with the dominance of group selection pressures. Better understanding of when individual perceptions, collective behavior, and ecological constraints align could also help scientists and policy makers understand where collective institutions constitute necessary social adaptations to environmental conditions and where education or policy incentives might be provided to shift from collective to individual action or adaptation. Finally, future research is needed to assist in the design and implementation of successful strategies for village-level adaptations.

\section{Study limitations}

Although our focus on a single village limits the initial generalizability of results, the findings from this representative case nevertheless represent a significant contribution to the literature on multilevel selection because it applies to adaptation. We demonstrate how an in-depth understanding of multilevel selection pressures can provide policy makers with valuable insights on how to target adaptation efforts, while also presenting hypotheses for future research and testing.

With respect to generalizability within Sri Lanka, according to local partners familiar with irrigation systems around the country, the structure of interactions between community members and local officials is representative of other minor tank, Sinhalese villages. Officials from the Department of Agrarian Development we interviewed in 2017 confirmed that the government takes a similar approach to interacting with minor-irrigation systems around the country and understands the ecological importance of collaboration in small-scale irrigation systems. Likewise, studies documenting cultural norms within Sri Lankan irrigation systems suggest that similar cultural norms and beliefs likely exist in other minor-tank systems (Mosse 1997, 1999). Therefore, 
recognizing that each community will have unique dynamics, we are confident that the dynamics presented here reflect how many minor-tank systems with a long history of irrigation are managed in modern times.

\section{CONCLUSION}

The above analysis demonstrates that despite significant changes in the social, political, and economic conditions, collective selection pressures continue to dominate decision making in Sri Lankan minor-tank systems. Widely acknowledged biological constraints in these minor systems and the social practices that likely coevolved to manage such constraints continue to compel individual farmers to adhere to collective cultivation rules and practices. By all accounts, individual deviation from collective practices is likely to result in suboptimal results for nonconforming individuals. Because farmers both experience and perceive the need to be in sync with one another to protect their own crops and those of their neighbors, farmers generally adhere to practices agreed upon in the seasonal meetings and coordinate application of inputs and harvesting practices with their neighbors. Individual decisions regarding which seeds to plant, when to plant, when to release water, and when to harvest are also heavily influenced by government recommendations and the community rules consolidated during seasonal meetings. Rather than undermine collective action, government involvement in community structures has largely served to reinforce collective behavior. Responsibility for infrastructure repairs, however, is an exception, where government interference lacks community buyin, resulting in predictable degradation.

These findings confirm that, as might be expected in a wellfunctioning CPR system, efforts to promote adaptation in minor systems are more likely to succeed if they target farmer organizations and the decisions taken in seasonal meetings instead of individual farmers. Although the need for collective adaptation may not be surprising in the context of CRP systems, it stands in contrast to many current adaptation policies and programs our team has observed over the course of our research, many of which focus on promoting individual adaptation to climate change. Existing community rule-making structures and ties between minor tank communities and government officials in Sri Lanka may present a unique opportunity to encourage collective agricultural adaptations. Indeed, the government's influence over seed varieties and planting times could be considered positive adaptation already in place. Additional research could therefore explore the possibilities for using current government-community interactions to forward other adaptation measures such as pest management and alternate wetting and drying.

Responses to this article can be read online at: http://www.ecologyandsociety.org/issues/responses. php/10175

\section{Acknowledgments:}

This research was supported by a grant from the U.S. National Science Foundation (NSF-EAR 1204685). We would like to thank our partners at the National Building Research Organization for helping to coordinate local research, including help with site selection and introductions to local officials. We would also like to thank Malaka Dhamruwan for his help in coordinating the research and our research assistants, Dilini Abeysekara, Ramesh Ranaweera, and Brindharshini Thiyagaraja. Publication of this article was funded by the University of Colorado Boulder Libraries Open Access Fund

\section{LITERATURE CITED}

Abeyratne, S., and J. Perera. 1986. Change and continuity in village irrigation systems: a case study in the Moneragala District of Sri Lanka. Agrarian Research and Training Institute, Colombo, Sri Lanka.

Adger, W. N. 2003. Social capital, collective action, and adaptation to climate change. Economic Geography 79 (4):387-404.

Anderson, R. S., E. Levy, and B. M. Morrison. 1991. Rice science and development politics: research strategies and IRRI's technologies confront Asian diversity (1950-1980). Oxford University Press, Oxford, UK.

Ariyabandu, R., 2008. Swings and roundabouts: a narrative on water policy development in Sri Lanka. Overseas Development Institute, London, UK. [online] URL: https://www.odi.org/sites/ odi.org.uk/files/odi-assets/publications-opinion-files/3359.pdf

Babel, M. S., A. Agarwal, D. K. Swain, and S. Herath. 2011. Evaluation of climate change impacts and adaptation measures for rice cultivation in northeast Thailand. Climate Research 46 (2):137-146. http://dx.doi.org/10.3354/cr00978

Banerjee, S., S. Das, A. Mukherjee, A. Mukherjee, and B. Saikia. 2016. Adaptation strategies to combat climate change effect on rice and mustard in Eastern India. Mitigation and Adaptation Strategies for Global Change 21(2):249-261. http://dx.doi. org/10.1007/s11027-014-9595-y

Bardhan, P., and J. Dayton-Johnson. 2002. Unequal irrigators: heterogeneity and commons management in large-scale multivariate research. Pages 87-112 in E. Ostrom, T. Dietz, N. Dolšak, P. C. Stern, S. Stonich, and E. U. Weber, editors. The drama of the commons. National Academies, Washington, D.C., USA.

Bastakoti, R. C., and G. P. Shivakoti. 2009. Context and institutions in irrigation management: applicability of design principles in Nepal and Thailand. M-POWER Working Paper MP-2009-06. Unit for Social and Environmental Research (USER) - Chiang Mai University, Chiang Mai, Thailand.

Belder, P., B. A. M. Bouman, R. Cabangon, L. Guoan, E. J. P. Quilang, L. Yuanhua, J. H. J. Spiertz, and T. P. Tuong. 2004. Effect of water-saving irrigation on rice yield and water use in typical lowland conditions in Asia. Agricultural Water Management 65 (3):193-210. http://dx.doi.org/10.1016/j.agwat.2003.09.002

Belder, P., J. H. J. Spiertz, B. A. M. Bouman, G. Lu, and T. P. Tuong. 2005. Nitrogen economy and water productivity of lowland rice under water-saving irrigation. Field Crops Research 93(2-3):169-185. http://dx.doi.org/10.1016/j.fcr.2004.09.022 
Bouman, B. A. M., and T. P. Tuong. 2001. Field water management to save water and increase its productivity in irrigated lowland rice. Agricultural Water Management 49:11-30. http://dx.doi.org/10.1016/S0378-3774(00)00128-1

Brewer, J. 2015. Tools for culture design: toward a science of social change? Systemic Change 1(1): 67-73.

Carr, E. R. 2014. From description to explanation: using the livelihoods as intimate government (LIG) approach. Applied Geography 52:110-122. http://dx.doi.org/10.1016/j.apgeog.2014.04.012

Cash, D. W., W. Adger, F. Berkes, P. Garden, L. Lebel, P. Olsson, L. Pritchard, and O. Young. 2006. Scale and cross-scale dynamics: governance and information in a multilevel world. Ecology and Society 11(2):8. http://dx.doi.org/10.5751/ES-01759-110208

Cox, M., and J. M. Ross. 2011. Robustness and vulnerability of community irrigation systems: the case of the Taos valley acequias. Journal of Environmental Economics and Management 61(3):254-266. http://dx.doi.org/10.1016/j.jeem.2010.10.004

Dasinaa, S., and M. Sugirtharan. 2017. Farmer adaptation on adverse climatic conditions in some irrigable areas of Trincomalee District, Sri Lanka. Pages 162-179 in Proceedings of Recognizing Climate Change Risk of Dry Zone Farmers. Colombo, Sri Lanka.

Dayton-Johnson, J., 2003. Small-holders and water resources: a review essay on the economics of locally-managed irrigation. Oxford Development Studies 31(3):315-339. http://dx.doi. org/10.1080/1360081032000111724

De Silva, C. S., E. K. Weatherhead, J. W. Knox, and J. A. Rodriguez-Diaz. 2007. Predicting the impacts of climate change: a case study of paddy irrigation water requirements in Sri Lanka. Agricultural Water Management 93(1-2):19-29. http://dx.doi. org/10.1016/j.agwat.2007.06.003

Dhawan, A. K., and R. Peshin. 2009. Integrated pest management: concept, opportunities and challenges. Integrated Pest Management: Innovation-Development Process 1:51-81. http://dx.doi.org/10.1007/978-1-4020-8992-3_2

Dunham, D. M. 1982. Politics and land settlement schemes: the case of Sri Lanka. Development and Change 13(1):43-61. http:// dx.doi.org/10.1111/j.1467-7660.1982.tb00112.x

Freeman, D. M. 1990. Designing local irrigation organizations for linking water demand with supply. Pages 111-140 in R. K. Sampath and R. A. Young, editors. Social, economic and institutional issues in Third World irrigation management. Westview, Boulder, Colorado, USA.

Government of Sri Lanka. 2010a. The national climate change adaptation strategy for Sri Lanka 2011 to 2016. Government of Sri Lanka, Colombo, Sri Lanka. [online] URL: https://www. climatechange.1k/adaptation/Files/Strategy Booklet-

Final for Print Low res(1).pdf

Government of Sri Lanka. 2010b. Sector vulnerability profile: agriculture and fisheries. Supplement document to the national climate change adaptation strategy for Sri Lanka 2011 to 2016. Government of Sri Lanka, Colombo, Sri Lanka.

Guneratne, A. 1985. Water, rice and people: problems and constraints of peasant colonization in the Dry Zone of Sri Lanka.
A thesis submitted to the Committee on Senior Fellowships. Dartmouth College, Hanover, New Hampshire, USA.

Hardin, G. 1968. The tragedy of the commons. Science 162 (3859):1243-1248. http://dx.doi.org/10.1126/science.162.3859.1243

Jinapala, K., L. Premadasa, P. G. Somaratne, and M. Samad. 2010. Managing irrigation jointly with farmers: history, present status and future: review of participatory irrigation management in Sri Lanka. Pages 35-63 in K. Jinapala, S. De Silva, M. M. M. Aheeyar, editors. Proceedings of the National Conference on Water, Food Security and Climate Change in Sri Lanka. International Water Management Institute, Colombo, Sri Lanka.

Kogan, M. 1998. Integrated pest management: historical perspectives and contemporary developments. Annual Review of Entomology 43:243-270. http://dx.doi.org/10.1146/annurev.ento.43.1.243

Kurukulasuriya, P., and R. Mendelsohn. 2008. Crop switching as a strategy for adapting to climate change. African Journal Agriculture and Resource Economics 2:105-126.

Leach, E. R. 1959. Hydraulic society in Ceylon. Past \& Present 15:2-26. http://dx.doi.org/10.1093/past/15.1.2

Leach, E. R. 1961. Pul Eliya, a village in Ceylon: a study of land tenure and kinship. Cambridge University Press, Cambridge, UK.

Lyon, B., L. Zubair, V. Ralapanawe, and Z. Yahiya. 2009. Finescale evaluation of drought in a tropical setting: case study in Sri Lanka. Journal of Applied Meteorology and Climatology 48 (1):77-88. http://dx.doi.org/10.1175/2008JAMC1767.1

Madani, K., and A. Dinar. 2012. Non-cooperative institutions for sustainable common pool resource management: application to groundwater. Ecological Economics 74:34-45. http://dx.doi. org/10.1016/j.ecolecon.2011.12.006

Mohottala Gedara, K. 2011. Optimal allocation of water in village irrigation systems of Sri Lanka. Dissertation. Queensland University of Technology, Brisbane, Queensland, Australia.

Mosse, D. 1997. The symbolic making of a common property resource: history, ecology and locality in a tank-irrigated landscape in south India. Development and Change 28(3):467-504. http://dx.doi.org/10.1111/1467-7660.00051

Mosse, D. 1999. Colonial and contemporary ideologies of 'community management': the case of tank irrigation development in South India. Modern Asian Studies 33(2):303-338. http://dx.doi.org/10.1017/S0026749X99003285

Olson, M. 1965. The logic of collective action. Harvard University Press, Cambridge, Massachusetts, USA.

Ostrom, E. 1990. Governing the commons: the evolution of institutions for collective action. Cambridge University Press, New York, New York, USA. http://dx.doi.org/10.1017/CBO9780511807763

Ostrom, E. 1993. Design principles in long-enduring irrigation institutions. Water Resources Research 29(7):1907-1912. http:// dx.doi.org/10.1029/92WR02991

Ostrom, E., and R. Gardner. 1993. Coping with asymmetries in the commons: self-governing irrigation systems can work. Journal of Economic Perspectives 7(4):93-112. http://dx.doi.org/10.1257/ jep.7.4.93 
Panabokke, C. R., R. Sakthivadivel, and A. D. Weerasinghe. 2002. Evolution, present status and issues concerning small tank systems in Sri Lanka. International Water Management Institute, Colombo, Sri Lanka. [online] URL: http://publications.iwmi.org/ pdf/H029980.pdf

Peebles, P. 2006. The history of Sri Lanka. Greenwood, Westport, Connecticut, USA.

Peshin, R., R. S. Bandral, W. Zhang, L. Wilson, and A. K. Dhawan. 2009. Integrated pest management: a global overview of history, programs and adoption. Pages 1-49 in R. Peshin and A. K. Dhawan, editors. Integrated pest management: innovationdevelopment process. Springer, New York, New York, USA. http:// dx.doi.org/10.1007/978-1-4020-8992-3_1

Reidsma, P., F. Ewert, A. O. Lansink, and R. Leemans. 2010. Adaptation to climate change and climate variability in European agriculture: the importance of farm level responses. European Journal of Agronomy 32(1):91-102. http://dx.doi.org/10.1016/j. eja.2009.06.003

Rejesus, R. M., F. G. Palis, D. G. P. Rodriguez, R. M. Lampayan, and B. A. M. Bouman. 2011. Impact of the alternate wetting and drying (AWD) water-saving irrigation technique: evidence from rice producers in the Philippines. Food Policy 36(2):280-288. http://dx.doi.org/10.1016/j.foodpol.2010.11.026

Richerson, P., R. Baldini, A. V. Bell, K. Demps, K. Frost, V. Hillis, S. Mathew, E. K. Newton, N. Naar, L. Newson, et al. 2016. Cultural group selection plays an essential role in explaining human cooperation: a sketch of the evidence. Behavioral Brain Science 39:e30. http://dx.doi.org/10.1017/S0140525X1400106X

Sarker, A., and T. Itoh. 2001. Design principles in long-enduring institutions of Japanese irrigation common-pool resources. Agricultural Water Management 48:89-102. http://dx.doi. org/10.1016/S0378-3774(00)00125-6

Seawright, J., and J. Gerring. 2008. Case selection techniques in case study research: a menu of qualitative and quantitative options. Political Research Quarterly 61(2):294-308. http://dx.doi. org/10.1177/1065912907313077

Senaratne, A., and H. Scarborough. 2011. Coping with climate variability by rain-fed farmers in Dry Zone, Sri Lanka: towards understanding adaptation to climate change. Pages 1-22 in 55th Annual Conference of the Australian Agricultural and Resource Economics Society, Melbourne, Australia.

Shah, T., M. Samad, R. Ariyaratne, and K. Jinapala. 2013. Ancient small-tank irrigation in Sri Lanka. Economic \& Political Weekly XLVILL(11):58-63.

Shrestha, S., P. Deb, and T. T. T. Bui. 2016. Adaptation strategies for rice cultivation under climate change in Central Vietnam. Mitigation and Adaptation Strategies for Global Change 21 (1):15-37. http://dx.doi.org/10.1007/s11027-014-9567-2

Somasiri, H. P. S., 2008. Participatory management in irrigation development and environmental management in Sri Lanka. Journal of Developments in Sustainable Agriculture 3(1):55-62.

Thiruchelvam, S. 2010. Agricultural production efficiency of bethma cultivation in Mahaweli System H. Sri Lankan Journal of Agricultural Economics 7:1-20. http://dx.doi.org/10.4038/sjae. $\underline{\mathrm{v} 7 \mathrm{i} 0.1820}$
Traulsen, A., and M. A. Nowak. 2006. Evolution of cooperation by multilevel selection. Proceeding of the National Academy of Sciences 103(29):10952-10955. http://dx.doi.org/10.1073/pnas.0602530103

Trawick, P. B. 2001. Successfully governing the commons: principles of social organization in an Andean irrigation system. Human Ecology 29(1):1-25. http://dx.doi.org/10.1023/A:1007199304395

Uphoff, N., M. Wickramasinghe, and C. Wijayaratna. 1990. "Optimum" participation in irrigation management: issues and evidence from Sri Lanka. Human Organization 49(1):26-40. http:// dx.doi.org/10.17730/humo.49.1.123pg568k4011351

Varela-Ortega, C., I. Blanco-Gutiérrez, P. Esteve, S. Bharwani, S. Fronzek, and T. E. Downing. 2016. How can irrigated agriculture adapt to climate change? Insights from the Guadiana Basin in Spain. Regional Environmental Change 16(1):59-70. http://dx.doi. org/10.1007/s10113-014-0720-y

Villholth, K. G., and L. D. Rajasooriyar. 2010. Groundwater resources and management challenges in Sri Lanka - an overview. Water Resources Management 24(8):1489-1513. http://dx.doi. org/10.1007/s11269-009-9510-6

Waring, T. M., M. A. Kline, J. S. Brooks, S. H. Goff, J. Gowdy, M. A. Janssen, P. E. Smaldino, and J. Jacquet. 2015. A multilevel evolutionary framework for sustainability analysis. Ecology and Society 20(2):34. http://dx.doi.org/10.5751/ES-07634-200234

Waring, T. M. and E. Tremblay. 2016. An evolutionary approach to sustainability science (with comment). Cliodynamics 7 (1):119-167.

Wassmann, R., S. V. K. Jagadish, K. Sumfleth, H. Pathak, G. Howell, A. Ismail, R. Serraj, E. Redona, R. K. Singh, and S. Heuer. 2009. Regional vulnerability of climate change impacts on Asian rice production and scope for adaptation. Advances in Agronomy 102:91-133. http://dx.doi.org/10.1016/S0065-2113(09) $\underline{01003-7}$

Weerahewa, J., S. S. Kodithuwakku, and A. Ariyawardana. 2010. The fertilizer subsidy program in Sri Lanka. In P. PinstrupAndersen and F. Cheng, editors. Food policy for developing countries: the role of government in the global food system. Cornell University, Ithaca, New York, USA.

Williams, G. C. 1966. Adaptation and natural selection: a critique of some current evolutionary thought. Princeton University Press, Princeton, New Jersey, USA.

Wilson, D. S., E. Ostrom, and M. E. Cox. 2013. Generalizing the core design principles for the efficacy of groups. Journal of Economic Behavior \& Organization 90:S21-S32. http://dx.doi. org/10.1016/j.jebo.2012.12.010

Yamane, A. 2009. Climate change and hazardscape of Sri Lanka. Environment and Planning A: Economy and Space 41 (10):2396-2416. http://dx.doi.org/10.1068/a41213

Yin, R. K. 2013. Case study research: design and methods. Sage, Thousand Oaks, California, USA 